\title{
Factors Related to Gender Differences in Toothbrushing Among Lithuanian Middle-Aged University Employees
}

\author{
Žana Sakalauskiené ${ }^{1}$, Miira M. Vehkalahti ${ }^{2}$, Heikki Murtomaa ${ }^{2}$, Vita Mačiulskiené ${ }^{1}$ \\ ${ }^{1}$ Faculty of Odontology, Medical Academy, Lithuanian University of Health Sciences, Kaunas, Lithuania, \\ ${ }^{2}$ Institute of Dentistry, University of Helsinki, Helsinki, Finland
}

Key words: toothbrushing; gender differences; dental attendance; dental health attitudes; knowledge of dental health.

Summary. Background and objectives. Many previous studies showed clear gender differences in the percentages of adults reporting toothbrushing more than once a day. This study evaluated the factors determining gender differences in toothbrushing among Lithuanian middle-aged university employees.

Material and Methods. A questionnaire survey was anonymously conducted among 35- to 44-year-old employees $(n=862)$ of four universities in Lithuania in 2005. The response rate was $64 \%(n=553)$. Data covered toothbrushing frequency, habitual dental attendance, dental health attitudes and knowledge, and subject's background information.

Results. Of all respondents, 68\% reported brushing their teeth more than once a day (73\% of women and $49 \%$ of men, $P<0.001)$ and $51 \%$ indicated checkup-based habitual dental attendance (54\% of women and $41 \%$ of men, $P=0.012$ ). The majority reported good dental status as being important to them and poor oral health as injurious to general health. Of all respondents, 44\% indicated that "Lack of time is the main reason for incomplete oral self-care" (61\% of men and 40\% of women, $P<0.001)$. Logistic regression models showed that the strongest factor affecting toothbrushing frequency was the importance of good dental health to them (OR, 1.6; 95\% CI, 1.1-2.4; $P=0.02)$ among women and statement that "Poor oral health can be injurious to general health" $(O R, 2.6 ; 95 \% C I, 1.2-5.5 ; P=0.01)$ and checkup-based habitual dental attendance $(O R, 2.4 ; 95 \%$ CI, 1.0-5.9; $P=0.06)$ among men.

Conclusions. Due to different determinants affecting toothbrushing frequency among men and women, different oral health motivation programs by gender should be developed.

\section{Introduction}

Among the goals set by the World Health Organization for 2020, there are objectives to develop accessible cost-effective oral health systems for the prevention and control of oral diseases and to develop oral health programs that will empower people to control determinants of their oral health (1).

An increased knowledge about the development and management of dental diseases emphasizes the important role of oral health behavior in preventing or arresting caries and periodontal diseases (2-5). Getting individuals to brush their teeth, together with regular visits to dental professional for reinforcement, seems to be the core pattern for the prevention of dental diseases $(2,5)$.

Toothbrushing is one of the most effective, inexpensive, and easy methods of dental plaque removal (6). Brushing teeth twice a day and flossing on a daily basis are current recommendations in many countries.

Correspondence to Ž. Sakalauskiené, Department of Dental and Maxillofacial Orthopedics, Medical Academy, Lithuanian University of Health Sciences, Sukilèliu 51, 50106 Kaunas, Lithuania. E-mail: zana.sakalauskiene@med.kmu.lt
Nationwide surveys show clear gender differences in the percentages of adults toothbrushing their teeth twice a day by country: $74 \%$ in the United Kingdom (83\% of women and $64 \%$ of men) (7), $68 \%$ in Denmark (77\% of women and $59 \%$ of men) (8), and $61 \%$ in Finland (76\% of women, $45 \%$ of men) (9). These figures dramatically differ from those of the Lithuanian survey where only 39\% of adults (50\% of women, $23 \%$ of men) reported brushing their teeth more than once a day (10). The rates in Lithuania are more similar to those in the neighboring Baltic countries: $45 \%$ of adults in Estonia (57\% of women, $30 \%$ of men) (11) and $43 \%$ of adults in Latvia (53\% of women, $31 \%$ of men) (12) reported brushing their teeth more than once a day.

Scarcity of data to understand differences in oral self-care by gender encourages attempts to identify and evaluate the determinants of this phenomenon for effective oral health promotion.

The aim of this study was to evaluate the factors

Adresas susirašinėti: Ž. Sakalauskienė, LSMU MA Veido ir žandikauliu ortopedijos klinika, Sukilèliu 51, 50106 Kaunas El. paštas: zana.sakalauskiene@med.kmu.lt 
related to gender differences in toothbrushing among Lithuanian middle-aged university employees.

\section{Material and Methods}

The Kaunas Regional Ethics Committee for Biomedical Research (Lithuania) granted its permission to conduct the present study.

A questionnaire survey was anonymously conducted among university employees from March to June 2005 (13). One university from every of the 4 university cities in Lithuania was invited to participate based on having no medical teaching profile. In every university, all employees aged 35 to 44 years $(\mathrm{n}=862 ; 629$ women and 233 men) received an envelope with the questionnaire together with an invitation letter explaining the study design and encouraging them to respond. They were asked to complete the questionnaire and return it anonymously to an indicated address (office/officer at the university) within two weeks. At returning the completed questionnaire, every respondent received a reward, a tube of toothpaste. The response rate was $64 \%(\mathrm{n}=553)$.

The self-administered questionnaire inquired about oral hygiene habits, self-assessed dental health and appearance, habitual dental attendance, and dental health knowledge and attitudes.

The question "How often do you normally brush your teeth?" offered five answering alternatives: more than once a day, once a day, almost daily, occasionally, and never. For the analyses, these alternatives were dichotomized as follows: more than once a day and less than that. Two respondents gave no information on their toothbrushing and were excluded from the present study.

Answering the question "How often do you use the following tools for interdental cleaning?" the answering alternatives were the same as for toothbrushing for each of the following three tools used for interdental cleaning: a toothpick, a dental floss, and an interdental brush. The missing answers were considered as never using the tool in question. For the analyses, the answers regarding every tool were dichotomized as follows: using it on a daily basis or not.

The questions "How would you assess your dental health?" and "How would you assess your dental appearance?" offered five answering alternatives: very good, good, poor, very poor, and no opinion, later dichotomized as good and poor. The answer "no opinion," reported by $1 \%$ of the respondents in both questions, was excluded from the analyses.

The self-reported number of lost teeth was inquired with six alternatives, later categorized as three: none, one to two teeth, and three and more teeth lost.

The question "How do you normally visit a den- tist?" indicated the respondent's habitual dental attendance being for the reason of checkup or in case of trouble only.

Dental health attitudes were described by the respondents' opinion on the following statements: "Good dental health is important to me," "Good dental appearance is important to me," and "Lack of time is the main reason for incomplete oral self-care," with every statement having five answering options from "entirely agree" to "entirely disagree." The same options were offered while assessing respondents' knowledge of dental health with the statement "Poor oral health can be injurious to general health."

The respondents' age, gender, marital status, education, and income served as background information. The respondents' age was evaluated by the question "When were you born?" with the answer required as the year of birth. Those born from 1960 to 1970 were defined as $35-44$ year olds. For reporting marital status, four options were given: married or living together, single, divorced, and widowed; these were later dichotomized as cohabiting and single. The level of education was reported as follows: lower than secondary school, secondary school, vocational school, and university education, later dichotomized as university education and lower. The question "What was your household income in litas per person a month during the past six months?" offered the following 4 options: less than 300 litas, 300-500 litas, 501-1000 litas, and more than 1000 litas, later categorized as below average (up to 500 litas), average (501-1000 litas), and above average (more than 1000 litas).

Statistical Analysis. Data were analyzed using the statistical package SPSS (version 12.0). Descriptive statistics included percentages. Their differences between the groups were analyzed with the chi-square test based on the corresponding frequencies. Multivariable analyses were performed by logistic regression models to evaluate the strength of the factors related to reporting toothbrushing more than once a day. The models simultaneously controlled for all other factors included. Goodness of fit was assessed by means of the Hosmer-Lemeshow test. Based on the estimates, produced by the models, odds ratios $(\mathrm{OR})$ and their 95\% confidence intervals (CI) were calculated. A $P$ value of less than 0.05 denoted statistical significance.

\section{Results}

A total of 553 subjects (64\%) responded; all were dentate. Their mean age was 40.11 years (SD, 3.19); the mean age of women and men was 40.10 (SD, 3.15) and 40.15 (SD, 3.36), respectively. There were $79 \%$ of women; $72 \%$ were married or cohabiting $(70 \%$ of women and $77 \%$ of men, $P=0.150)$, $82 \%$ had university education $(83 \%$ of women and 
$78 \%$ of men, $P=0.238)$, and $39 \%$ reported a medium household income (40\% of women and 34\% of men), with $38 \%$ being below ( $40 \%$ of women and $32 \%$ of men) and $23 \%$ above that (20\% of women and $34 \%$ of men) $(P=0.003)$. Of all the respondents, $68 \%$ reported brushing their teeth more than once a day. This habit was more frequent among women than men $(73 \%$ vs. $49 \%, P<0.001)$. Interdental cleaning on a daily basis was most frequently reported as cleaning using a toothpick (38\%), followed by a dental floss (26\%) and an interdental brush (19\%), a dental floss being indicated more frequently by women than men. Of the respondents, 55\% reported using interdental cleaning tools on a daily basis, and $3 \%$ of the respondents reported never using any of such tools.

The majority assessed their dental appearance $(72 \%)$ and their dental health $(73 \%)$ as very good or good with no difference by gender.

Of all the respondents, $21 \%$ reported no teeth lost, $39 \%$ had lost one-to-two teeth, and $40 \%$ more than one or two.

A checkup as the reason for habitual dental attendance was reported by $51 \%$ of the respondents ( $54 \%$ of women vs. $41 \%$ of men, $P=0.012$ ).

Almost all stated that good dental health (98\%) and appearance (97\%) was important to them and that poor oral health could be injurious to general health (97\%). A greater percentage of women than men entirely agreed with the statement that dental appearance was important to them (68\% vs. $50 \%$, $P<0.001)$. Nearly half of the respondents $(44 \%)$ agreed with the statement "Lack of time is the main reason for incomplete oral self-care" (61\% of men and $40 \%$ of women, $P<0.001)$.

Gender differences in toothbrushing frequency were statistically significant within most of the subgroups according to the respondents' characteristics (Tables 1 and 2). Bivariate analyses separately for women and men revealed that toothbrushing more than once a day among women was more prevalent among those with university education (75\% vs. $60 \% ; P=0.009$ ) (Table 1 ) and among those entirely agreeing with the importance of good dental health to them (77\% vs. $63 \% ; P=0.004)$ (Table 2). Among men, good self-assessed dental appearance, checkup-based dental attendance, and disagreement with the statement "Lack of time is the main reason for incomplete oral self-care" were significant determinants of toothbrushing more than once a day (Table 2).

Similar logistic regression models were fitted to the data separately for women and men in order to show the strength of the factors related to reporting toothbrushing more than once a day. For women (Table 3), the strongest factor was the importance of good dental health to them (OR, 1.6; 95\% CI, $1.1-2.4 ; P=0.02$ ). For men (Table 4), the strongest factors were agreeing with the statement "Poor oral health can be injurious to general health" (OR, 2.6; 95\% CI, 1.2-5.5; $P=0.01)$, reporting checkupbased dental attendance (OR, 2.4; 95\% CI, 1.0-5.9; $P=0.06$ ), and disagreeing with the statement "Lack of time is main reason for incomplete oral self-care" (OR, 1.5; 95\% CI, 1.1-2.0; $P=0.02$ ).

\section{Discussion}

The present study revealed a clear gender differ-

Table 1. Frequency of Toothbrushing More Than Once a Day as Reported by 35- to 44-Year-Old University Employees ( $\mathrm{n}=551$ ) in Lithuania According to Their Background Characteristics, Separately for Women and Men

\begin{tabular}{|c|c|c|c|c|c|}
\hline \multirow{2}{*}{ Characteristic } & \multicolumn{2}{|c|}{ Women } & \multicolumn{2}{|c|}{ Men } & \multirow{2}{*}{$\begin{array}{c}\text { Gender Difference } \\
\text { Pearson Chi-Square } \\
P \text { Value }\end{array}$} \\
\hline & $\mathrm{n}$ & $\%$ & $\mathrm{n}$ & $\%$ & \\
\hline All respondents & 438 & 73 & 113 & 49 & $21.879 ;<0.001$ \\
\hline \multicolumn{6}{|l|}{ Marital status } \\
\hline Cohabiting & 309 & 71 & 88 & 48 & $15.786 ;<0.001$ \\
\hline Single & 129 & 78 & 25 & 56 & $5.044 ; 0.025$ \\
\hline Pearson chi-square; $P$ value & \multicolumn{2}{|c|}{$2.222 ; \quad P=0.136$} & \multicolumn{2}{|c|}{$0.533 ; \quad P=0.465$} & \\
\hline \multicolumn{6}{|l|}{ Education } \\
\hline University & 362 & 75 & 88 & 50 & $21.393 ;<0.001$ \\
\hline Lower than university & 76 & 60 & 25 & 48 & $1.207 ; 0.272$ \\
\hline Pearson chi-square; $P$ value & \multicolumn{2}{|c|}{$6.742 ; \quad P=0.009$} & \multicolumn{2}{|c|}{$0.031 ; P=0.860$} & \\
\hline \multicolumn{6}{|l|}{ Income* } \\
\hline Above average & 85 & 80 & 39 & 54 & $9.026 ; 0.003$ \\
\hline Average & 175 & 73 & 38 & 55 & $4.748 ; 0.029$ \\
\hline Below average & 174 & 69 & 35 & 37 & $12.752 ;<0.001$ \\
\hline Pearson chi-square; $P$ value & \multicolumn{2}{|c|}{ 3.529; $P=0.171$} & \multicolumn{2}{|c|}{$2.931 ; \quad P=0.231$} & \\
\hline
\end{tabular}

\footnotetext{
*No information on income $(\mathrm{n}=5)$.
} 
Table 2. Percentages of Toothbrushing More Than Once a Day as Reported by 35- to 44-Year-Old University Employees $(\mathrm{N}=551)$ in Lithuania According to Self-Assessed Dental Appearance, Self-Reported Number of Teeth Lost, Habitual Dental Attendance and Opinions About Statements Related to Dental Health Attitudes and Knowledge, Separately for Women and Men

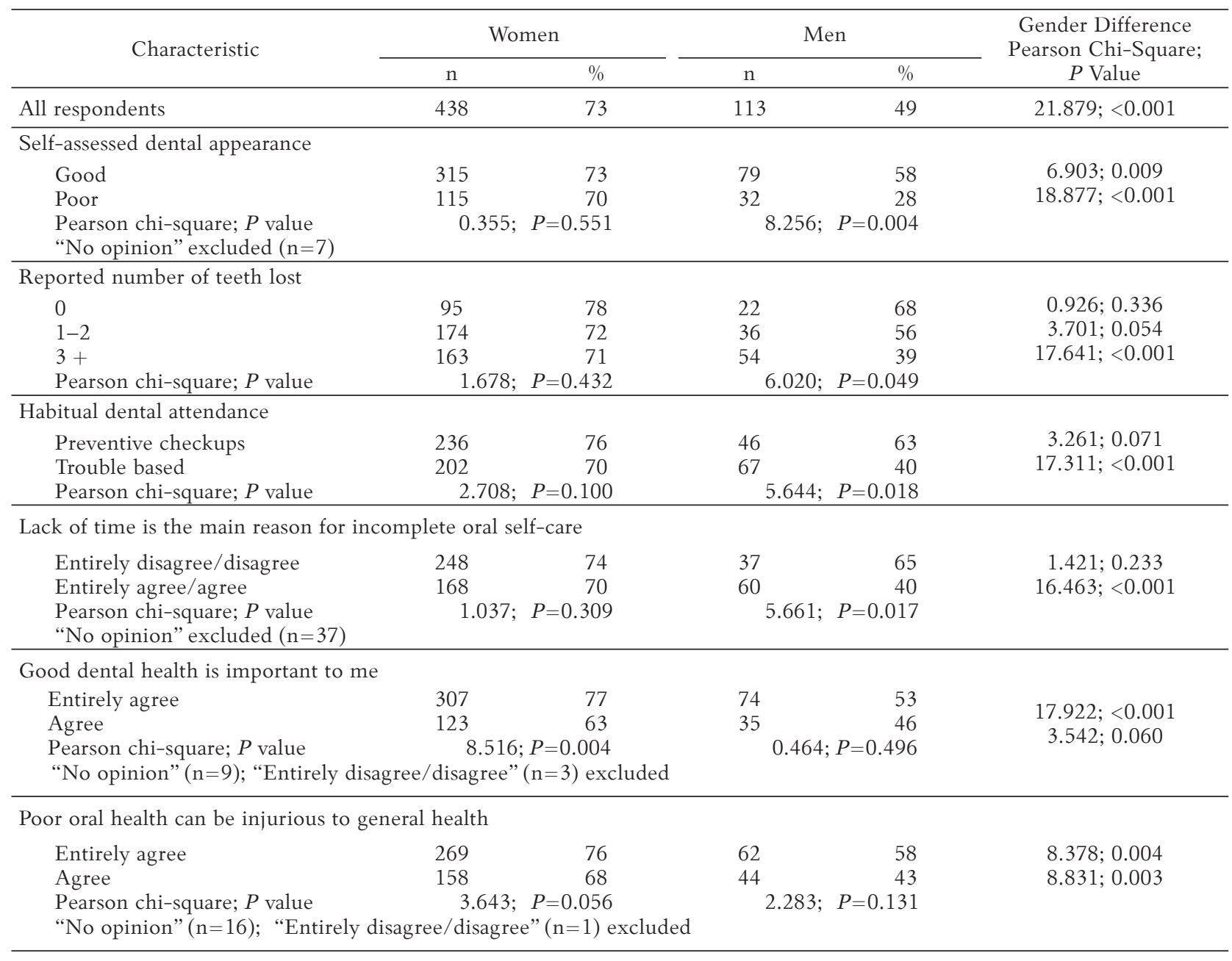

Table 3. Factors Related to Reporting Toothbrushing More Than Once a Day Among 35-44-Year-Old Female University Employees $(n=438)$ in Lithuania by Means of a Logistic Regression Model

\begin{tabular}{|c|c|c|c|c|c|}
\hline \multirow[t]{2}{*}{ Factor and Its Categories } & \multicolumn{2}{|c|}{ Estimate of Strength } & \multicolumn{2}{|c|}{$\begin{array}{l}\text { Odds Ratio (OR) and Its } 95 \% \\
\text { Confidence Interval (CI) }\end{array}$} & \multirow[t]{2}{*}{$P$ value } \\
\hline & Estimate & SE & OR & $95 \% \mathrm{CI}$ & \\
\hline Age: from 35 to 44 years & -0.022 & 0.036 & 1.0 & $0.9,1.1$ & 0.554 \\
\hline Education level: $1=$ less than secondary school, $4=$ university & 0.141 & 0.215 & 1.2 & $0.8,1.8$ & 0.510 \\
\hline Marital status: $1=$ single, $2=$ cohabiting & -0.352 & 0.257 & 0.7 & $0.4,1.2$ & 0.171 \\
\hline Income level: $1=$ low, $4=$ high & 0.211 & 0.141 & 1.2 & $0.9,1.6$ & 0.136 \\
\hline $\begin{array}{l}\text { Poor oral health can be injurious to general health: entirely } \\
\text { disagree }=1 \text {, entirely agree }=5\end{array}$ & 0.233 & 0.217 & 1.3 & $0.8,1.9$ & 0.285 \\
\hline $\begin{array}{l}\text { Good dental health is important to me: entirely disagree }=1 \text {, } \\
\text { entirely agree }=5\end{array}$ & 0.479 & 0.206 & 1.6 & $1.1,2.4$ & 0.020 \\
\hline $\begin{array}{l}\text { Lack of time is the main reason for incomplete oral self-care: } \\
\text { entirely agree }=1 \text {, entirely disagree }=5\end{array}$ & 0.123 & 0.082 & 1.1 & $1.0,1.3$ & 0.132 \\
\hline $\begin{array}{l}\text { Habitual dental attendance: trouble-based }=1 \text {, preventive } \\
\text { checkups }=2\end{array}$ & 0.172 & 0.226 & 1.2 & $0.8,1.9$ & 0.447 \\
\hline Constant & -2.754 & 2.091 & - & - & - \\
\hline
\end{tabular}

Hosmer-Lemeshow test: $P=0.568$. Overall percentage 74.1 . 
Table 4. Factors Related to Reporting Toothbrushing More Than Once a Day Among 35-44-Year-Old Male University Employees $(\mathrm{N}=113)$ in Lithuania by Means of a Logistic Regression Model

\begin{tabular}{|c|c|c|c|c|c|}
\hline \multirow[t]{2}{*}{ Factor and Its Categories } & \multicolumn{2}{|c|}{ Estimate of Strength } & \multicolumn{2}{|c|}{$\begin{array}{l}\text { Odds Ratio (OR) and Its 95\% } \\
\text { Confidence Interval (CI) }\end{array}$} & \multirow[t]{2}{*}{$P$ value } \\
\hline & Estimate & SE & $\mathrm{OR}$ & $95 \% \mathrm{CI}$ & \\
\hline Age: from 35 to 44 years & -0.018 & 0.063 & 1.0 & $0.9,1.1$ & 0.779 \\
\hline $\begin{array}{l}\text { Education level: } 1=\text { less than secondary school, } \\
4=\text { university }\end{array}$ & -0.113 & 0.403 & 0.9 & $0.4,2.0$ & 0.778 \\
\hline Marital status: $1=$ single, $2=$ cohabiting & -0.307 & 0.523 & 0.7 & $0.3,1.9$ & 0.479 \\
\hline Income level: $1=$ low, $4=$ high & 0.186 & 0.250 & 1.2 & $0.7,2.0$ & 0.458 \\
\hline $\begin{array}{l}\text { Poor oral health can be injurious to general health: } \\
\text { entirely disagree }=1 \text {, entirely agree }=5\end{array}$ & 0.946 & 0.384 & 2.6 & $1.2,5.5$ & 0.014 \\
\hline $\begin{array}{l}\text { Good dental health is important to me: entirely } \\
\text { disagree }=1 \text {, entirely agree }=5\end{array}$ & -0.317 & 0.390 & 0.7 & $0.3,1.6$ & 0.416 \\
\hline $\begin{array}{l}\text { Lack of time is the main reason for incomplete oral } \\
\text { self-care: entirely agree }=1 \text {, entirely disagree }=5\end{array}$ & 0.383 & 0.169 & 1.5 & $1.1,2.0$ & 0.024 \\
\hline $\begin{array}{l}\text { Habitual dental attendance: trouble-based }=1 \text {, reg- } \\
\text { ularly for checkups }=2\end{array}$ & 0.868 & 0.466 & 2.4 & $1.0,5.9$ & 0.063 \\
\hline Constant & -3.317 & 3.220 & - & - & - \\
\hline
\end{tabular}

Hosmer-Lemeshow test: $P=0.678$. Overall percentage 67.9.

ence in factors related to toothbrushing frequency. However, it was associated with different attitudes toward dental health in both genders. The results of the present study showed that women and men had different beliefs about dental health that may influence the toothbrushing frequency. Toothbrushing frequency among women was associated with strong agreement with the statement about importance of dental health to them. However, among men, the reported checkup-based dental attendance as well as disagreement with the statement "Lack of time is the main reason for incomplete oral self-care" correlated with their toothbrushing frequency. The results partly support an earlier notion of poor correlation of knowledge and health-enhancing behavior (14). It therefore appears from the results that knowledge of dental health may influence toothbrushing frequency only for men. Even though the vast majority of all respondents stated that poor oral health could be injurious to general health, this seemed to be associated with toothbrushing frequency among men only. Despite the fact that a significantly greater percentage of women than men entirely agreed that dental appearance was important to them, this belief was not related to toothbrushing more than once a day among women.

No common factors were found to be associated with toothbrushing frequency for both genders. The reported higher frequency of toothbrushing was observed among women with university education as compared with the lower levels of education, while among men, it was related to better self-assessment of dental appearance, fewer reported teeth lost, and more frequently indicated checkup-based reason for the habitual dental attendance.
It has been previously shown that women exhibit better oral self-care than men do. However, there are almost no studies analyzing the factors associated with preventive oral self-care by gender. In Japan, a study among adults has demonstrated that the factors affecting preventive oral self-care behavior differ by gender and that health behavior is more elusive in men than women (15). These results emphasize the need for further research to understand the sources of gender differences in dental health behavior.

The results of the present study support previous findings from various countries demonstrating that gender $(8,9,15-20)$, socioeconomic factors $(16,18,20-22)$, education $(8,17,21)$, preventive dental attendance $(8,21)$, favorable attitudes and beliefs about dental health $(23,24)$ are important determinants that affect toothbrushing frequency, with gender being the strongest one. A recent study among elderly dental patients in Lithuania reports no gender difference in toothbrushing frequency but in line with our results shows great differences according to the level of education (25).

Analysis of differences in health behavior of women and men showed that gender differences in preventive oral self-care were observed already among adolescents - girls demonstrated better knowledge of dental health, sound teeth were more important to them, and they practiced dental hygiene habits more frequently (26). Apparently, these differences persist into adulthood, possibly because of parents' oral self-care reflection on their children's corresponding behavior (27). Thus, gender differences related to oral health could be transmitted between generations. The significance of mothers' and fa- 
thers' roles as a model for behavior of their children is an important issue for further studies.

The limitation of the present study is a restricted sample of middle-aged, urban, female-dominated target group with a high level of education and most commonly with an average income or income above average in Lithuania. Among the respondents, the majority $(79 \%)$ were women, closely corresponding to gender distribution in the target population of middle-aged university employees (73\% of women vs. $27 \%$ of men). Taking into consideration the above-mentioned aspects of the study sample, this group of individuals is likely to represent most favorable preventive dental health behavior in the country. Good oral hygiene is generally considered as socially acceptable behavior, and consequently, the individuals with higher education may express the wish to demonstrate more of it than it is in reality. Thus, some overreporting of preventive oral hygiene habits as well as dental health attitudes and knowledge might have happened (28). Still, this group with higher socioeconomic status reported similar or lower rates of oral self-care than those found in national studies in Western European countries. This situation calls for more emphasis on implementing oral self-care promotion programs within Lithuanian adult population, for men in particular.

\section{Conclusions}

Due to the different determinants affecting toothbrushing frequency among men and women, different, gender-focused health education and motivation programs are advisable to strengthen preventive oral self-care among adults. A special emphasis should be placed on men representing high-risk group in this context. More studies involving high-risk individuals are needed to identify behavior-related factors in order to optimize oral health care.

\section{Statement of Conflict of Interest}

The authors state no conflict of interest.

\title{
Lietuvos universitetų vidutinio amžiaus darbuotojų dantų valymo ipročių skirtumai susiję su lytimi
}

\author{
Žana Sakalauskiené ${ }^{1}$, Miira M. Vehkalahti ${ }^{2}$, Heikki Murtomaa ${ }^{2}$, Vita Mačiulskiené ${ }^{1}$ \\ ${ }^{1}$ Lietuvos sveikatos mokslu universiteto Medicinos akademijos Odontologijos fakultetas, \\ ${ }^{2}$ Helsinkio universiteto Odontologijos institutas
}

Raktažodžiai: dantų valymas, lyčių skirtumai, lankymasis pas odontologą, dantų sveikatos elgsena, žinios apie dantų sveikatą.

Santrauka. Tyrimo pagrindas ir tikslai. Daugeliu anksčiau atliktų tyrimų įrodytas dantų valymo skirtumas tarp lyčių, įvertinus suaugusiųjų ịpročius valyti dantis daugiau nei vieną kartą per dieną. Šikart tyrėme veiksnius, lemiančius dantų valymo dažnumo skirtumus tarp lyčių Lietuvos universitetų vidutinio amžiaus darbuotojų grupėje.

Tyrimo medžiaga ir metodai. 35-44 metų keturių Lietuvos universitetų darbuotojai (n=862) $2005 \mathrm{~m}$. buvo anonimiškai apklausti naudojant klausimyną. 64 proc. $(n=553)$ apklaustųjų grąžino užpildytas anketas. Anketose buvo pateikti klausimai apie dantų valymo dažnumą, apie ịprastinio lankymosi pas odontologą priežastis, apie dantų sveikatos elgseną ir žinias, apie tiriamojo demografinius duomenis.

Rezultatai. Iš visų apklaustųiu 68 proc. teige valantys dantis dažniau nei vieną kartą per dieną, žymiai daugiau moterų nei vyrų (73 proc. palyginti su 49 proc., $\mathrm{p}<0,001)$, 51 proc. iš jų nurodè profilaktinę patikrą kaip pagrindinę íprastinio lankymosi pas odontologą priežastį, moterys žymiai dažniau nei vyrai (54 proc. palyginti su 41 proc., $\mathrm{p}=0,012$ ). Dauguma teigè, kad dantų sveikatos būklè jiems svarbi bei pritarè teiginiui, kad prasta burnos sveikata gali turèti ịtakos bendrai sveikatai. Iš visų tiriamųjų 44 proc. sutiko, kad pagrindinè nepakankamo rūpinimosi savo burnos sveikata priežastis jiems yra laiko trūkumas, žymiai daugiau vyrų nei moterų (61 proc. palyginti su 40 proc., p<0,001). Logistinès regresijos modeliai parodė, kad stipriausias veiksnys, turintis įtakos dantų valymo dažnumui moterims, yra geros dantų sveikatos palaikymo svarba ( šansų santykis - 1,6; 95 proc. PI - 1,1-2,4; p=0,02), o vyrams - įsitikinimas, kad prasta burnos sveikata gali turèti įtakos bendrai sveikatai (šansų santykis - 2,6; 95 proc. PI - 1,2-5,5; $p=0,01$ ) bei ipprastinis lankymasis pas odontologą profilaktiškai (šansų santykis $-2,4 ; 95$ proc. PI $-1,0-5,9 ; \mathrm{p}=0,06$ ).

Išvada. Moterų ir vyrų dantų valymo dažnumui įtakos turi skirtingi veiksniai, todèl turi būti kuriamos skirtingos burnos sveikatos elgseną skatinančios programos vyrams ir moterims atsižvelgiant ị lyčių skirtumus. 


\section{References}

1. Hobdell M, Petersen PE, Clarkson J, Johnson N. Global goals for oral health 2020. Int Dent J 2003;53:285-8.

2. Löe H. Oral hygiene in the prevention of caries and periodontal disease. Int Dent J 2000;50:129-39.

3. Teng HC, Lee CH, Hung HC, Tsai CC, Chang YY, Yandg $\mathrm{YH}$, et al. Lifestyle and psychosocial factors associated with chronic periodontitis in Taiwanese adults. J Periodontol 2003;74:1169-75.

4. Sanders AE, Spencer AJ, Slade GD. Evaluating the role of dental behaviour in oral health inequalities. Community Dent Oral Epidemiol 2006;34:71-79.

5. Augner R. Tooth brushing as routine behaviour. Int Dent J 2007;57:364-76

6. Ashley P. Tooth brushing: why, when and how? Dent Update 2001;28:36-40.

7. Brandock G, White DA, Nuttall NM, Morris AJ, Treasure ET, Pine CM. Dental attitudes and behaviours in 1998 and implications for the future. Br Dent J 2001;190: 228-32.

8. Christenssen LB, Petersen PE, Krustrup U, Kjøller M. Selfreported oral hygiene practices among adults in Denmark. Community Dent Health 2003;20:229-35.

9. Suominen-Taipale L, Nordblad A, Vehkalahti M, Aromaa A (eds). Oral health in the Finnish adult population. Health 2000 Survey. Publication of the National Public Health Institute. Hakapaino Oy, Helsinki 2008; B 25/2008. Available from: URL: http://www.terveys2000.fi/julkaisut/oral health.pdf

10. Grabauskas V, Klumbienė J, Petkevičienė J, Šakytė E, Kriaučionienè V, Paalanen L, et al. Health behaviour among Lithuanian adult population, 2006. Finland; Helsinki: National Public Health Institute 2007;B 7/2007.

11. Kasmel A, Lipand A, Kasmel K, Markina A, Prättälä R, Helasoja V, et al. Health behaviour among Estonian adult population, spring 1998. Finland; Helsinki: National Public Health Institute 1999;B 11/1999.

12. Pudule I, Vileruša A, Grinberga D, Velika B, Tilgale N, Dzerve $\mathrm{V}$, et al. Health behaviour among Latvian adult population, 2006. Finland; Helsinki: National Public Health Institute; 2007;B 27/2007.

13. Sakalauskienė Ž, Mačiulskienė V, Vehkalahti MM, Kubilius R, Murtomaa H. Characteristics of dental attendance among Lithuanian middle-aged university employees. Medicina (Kaunas) 2009;45:312-9.

14. Blinkhorn AS. Dental health education: what lessons have we ignored? Br Dent J 1998;184:58-9.

15. Tada A, Hanada N. Sexual differences in oral health behaviour and factors associated with oral health behaviour in Japanese young adults. Public Health 2004;118:104-9.

16. Murtomaa H, Metsäniitty M. Trends in tooth brushing and utilization of dental services in Finland. Community Dent Oral Epidemiol 1994;22:231-4.

17. Payne BJ, Locker D. Relationship between dental and general health behaviors in a Canadian population. I Public Health Dent 1996;56:198-204.

18. Sakki TK, Knuuttila MLE, Anttila SS. Lifestyle, gender and occupational status as determinants of dental health behavior. J Clin Periodontol 1998;25:566-70.

19. Maes L, Vereecken C, Vanobbergen J, Honkala S. Tooth brushing and social characteristics of families in 32 countries. Int Dent I 2006;56:159-67.

20. Artnik B, Premik M, Zaletel-Kragelj L. Population groups at high risk for poor oral self care: the basis for oral health promotion. Int J Public Health 2008;53:195-203.

21. Paunio P. Dental health habits of young families from Southwestern Finland. Community Dent Oral Epidemiol 1994;22:36-40.

22. Tada A, Matsukubo T. Relationship between oral health behaviors and general health behaviors in a Japanese adult population. J Public Health Dent 2003;63:250-4.

23. Savolainen IJ, Suominen-Taopale AL, Uutela AK, Martelin TP, Niskanen MC, Knuuttila ML. Sense of coherence as a determinant of tooth brushing frequency and level of oral hygiene. J Periodontol 2005;76:1006-12.

24. Riley JL 3rd, Gilbert GH, Heft MW. Dental attitudes: proximal basis for oral health disparities in adults. Community Dent Oral Epidemiol 2006;34:289-98.

25. Vyšniauskaitė S, Kammona N, Vehkalahti MM. Number of teeth in relation to oral health behavior in dentate elderly patients in Lithuania. Gerodontology 2005;22:44-51.

26. Ostberg AL, Halling A, Lindblad U. Gender differences in knowledge, attitude, behavior and perceived oral health among adolescents. Acta Odontol Scand 1999;57:231-6.

27. Poutanen R, Lahti S, Tolvanen M, Hausen H. Gender differences in child-related and parent-related determinants of oral health-related lifestyle among 11- to 12-year-old Finnish schoolchildren. Acta Odontol Scand 2007;65:194-200.

28. Sjöström O, Holst D. Validity of a questionnaire survey: response patterns in different subgroups and the effect of social desirability. Acta Odontol Scand 2002;60:136-40. 